\title{
VITAMIN (E) PROTECTIVE ROLE AGAINST ROUNDUP TESTICULAR GENOTOXICITY IN MALE RATS
}

\author{
Samah F. Ibrahim *, Mona M. Ali *, Heba El Malt ** and Manal Ewaiss *** \\ *Lecturer of forensic medicine and clinical toxicology- Kasr Alaini- Cairo University. \\ **Lecturer of medical biochemistry and molecular biology, National Research Center. \\ $* * *$ Lecturer of medical biochemistry and molecular biology .faculty of medicine, Beni sueif \\ universty
}

\section{ABSTRACT}

Round up, a worldwide herbicide has cellular and genotoxic effects. Round up's genotoxicity was tested by detecting the expression of the steroidogenic acute regulatory, aromatase, estrogen and androgen receptor genes in testicular cells. Its cytotoxicity was examined by measuring caspase 3 gene expressions. Genes' expressions were assessed by RT- PCR. Testicular lesions were detected by histopathological examination. We determined the role of vitamin $\mathrm{E}$ in reducing its toxic effects. Our study determined that Round up toxic doses caused endocrinal disruption through alteration of genes expression and effects on cellular integrity by increasing apoptosis. Administration of the vitamin $\mathrm{E}$ during exposure can reduce and protect against these endocrine cytogenotoxic effects.

Key words: (Round up, genotoxicity, testicular, RT-PCR and Vit E).

\section{INTRODUCTION:}

Agricultural production depends heavily on the use of agrochemicals e.g. herbicides are used to control weeds in farms. Humans are exposed daily directly or indirectly to the applied herbicides, which is present as pollutants. One of them is Round up, commercialized glyphosate -based herbicide (Feron et al., 2002; Gobi and Gunasekaran, 2010).

Roundup is the first herbicide used worldwide, and is a one of the major pollutant of rivers and surface waters. It contaminates ecosystems and its increased presence in the food chain has been demonstrated (Gasnier et al., 2009). Roundup is one the most used herbicides in Egypt since 2000 (Battaglin et al., 2005).

A glyphosate-based herbicide Roundup affects human-beings at the cellular, physiological and molecular levels (Fournier et al., 2000).
Although, studies regarding the biological effects of herbicides have increased, the exact mechanism by which glyphosate exerts its toxic effects in humans or experimental mammals is not clear and its results on the genotoxicity are often incomplete and sometimes contradictory (Siu et al., 2008).

Antioxidant vitamins are able to inactivate highly reactive molecules, such as free radicals, that are generated during various biochemical processes in the cells. A large number of antioxidants like vitamin $\mathrm{C}, \mathrm{E}$ and plant derivatives have been tested in the experimental animals in reducing the clastogenicity induced by drugs (Costa and Nepomuceno, 2006). The protective effects of vitamin $\mathrm{E}$ against pesticide-induced toxicity have been reported. In addition, vitamin $\mathrm{E}$ has been shown to be effective in reducing effects of various genotoxic compounds 
(Altuntas and Delibas 2002). Of the antioxidants tested, vitamin $\mathrm{E}$ shows the most promising effect in reducing genotoxic cellular effects induced by chemicals. However, no information is available concerning the effect of vitamin $\mathrm{E}$ against Roundup induced cytogenotoxicity. Therefore, in the present study we evaluated the cytogenotoxicity induced by Roundup and the possible beneficial effect of vitamin $\mathrm{E}$ against Roundup induced cytogenotoxicity using RT- PCR and histological examination.

\section{MATERIAL \& METHODS}

\section{Chemicals:}

Roundup (Technical grade, 48\%) was purchased from -Monsanto Europe-SA. (Belgium). Vitamin E (tocopheryl acetate, trade name-Evion) was procured from Merck Pharmaceuticals (200 mg capsules).

\section{Animals:}

A total of twenty male rats (Wister strain), weighing about 100-120 grams were used in the study as our main aim was to detect genotoxicity in testicular tissue. Previous studies have shown that males tend to be more susceptible than females to the genotoxic effects of various chemicals (Faiola et al., 2004). The animals were housed in polypropylene cages, given water ad libitum and fed a standard pellet diet. The rats were segregated into 2 groups consisting of 10 animals each. Animals in each group were further subdivided into 2 sub-groups and were treated with Roundup alone or with Roundup plus vitamin $\mathrm{E}$ daily for a period of 30 days as described below.

Animals in the control group received $1 \mathrm{ml}$ of corn oil, orally. Roundup treated groups (exposed groups) were given Roundup (500- $\mathrm{mg} / \mathrm{kg}$ body weight (group1) and 750 $\mathrm{mg} / \mathrm{kg}$ body weight (group2) modified from (Ikpeme et al., 2006) dissolved in corn oil. Animals in the Roundup + vitamin $\mathrm{E}$ groups (protected groups) received Roundup (500-mg/kg body weight (group1) and $750-\mathrm{mg} / \mathrm{kg}$ body weight (group2)) dissolved in corn oil, orally and vitamin E $(200 \mathrm{mg} / \mathrm{kg}$ body weight) subcutaneously. The dose of vitamin $E$ used was based on the dose that was seen to be most effective in lowering toxicity induced by various xenobiotics (Yousef et al., 2006). At the end of the respective treatments rats were sacrificed under light ether anesthesia followed by cervical dislocation and their testicles removed.

Quantitative real-time RT-PCR for mRNA analysis:

Quantitative real-time PCR was performed to assess the mRNA levels of the studied genes using step one plus (Applied Biosysyem,USA). Total RNA was extracted from testicular tissue homogenate using using RNeasy Purification Reagent (Qiagen, Valencia, CA) according to the manufacturer's instructions. The purity (A260/A280 ratio) and the concentration of RNA were obtained using spectrophotometry (Gene Quant 1300, Uppsala, Sweden). RNA quality was confirmed by gel electrophoresis, and mRNA was reverse-transcribed using the Transcriptor First Strand cDNA Synthesis kit (Roche).

Primers (Table1) were synthesized by Metabion International (Martinsried,Germany). GAPDH gene was used as the reference (housekeeping) gene (Table 1). Twenty microliters of a reaction mixture consisting of FastStart DNA MasterPLUS SYBR Green I (Roche), the forward and reverse primers, and an 
aliquot of the reverse-transcribed samples $(2 \mu \mathrm{l})$ were used. PCR reactions consisting of $95^{\circ} \mathrm{C}$ for $10 \mathrm{~min}$ (1 cycle), $94^{\circ} \mathrm{C}$ for $15 \mathrm{~s}$, and $60^{\circ} \mathrm{C}$ for 1 min (40 cycles), data was analyzed with the ABI Prism sequence detection system software and quantified using the v1•7 Sequence Detection Software from PE Biosystems (Foster City, CA). Relative expression of studied genes was calculated using the comparative threshold cycle method. All values were normalized to the GAPDH genes R1 (Livak and Schmittgen, 2001).

Tissue processing for histological examination

The testicular tissues from different groups were embedded in formalinefixed paraffin and $5 \mu \mathrm{m}$ thick sections were prepared. These sections were stained with Hematoxylin and Eosin and examined by light microscope.

\section{Statistical methods}

Data were statistically described in terms of mean \pm standard deviation. Comparison of quantitative variables was done using Mann- Whitney test. Correlation was done to test for linear relations between quantitative variables by Spearman correlation coefficient. A probability value ( $\mathrm{P}$ value) less than 0.05 was considered statistically significant. All statistical calculations were done using SPSS (Statistical Package for the Social Science; SPSS Inc., Chicago, IL, USA) version 21 (Chan, 2003).

\section{RESULTS}

Roundup genotoxicity was conducted by PCR using five genes; aromatase gene, steroidogenic acute regulatory (STAR) gene, estrogen receptor gene, androgen receptor gene and caspase 3 gene.

The expression of all genes was significantly decreased in exposed groups except caspase 3 which was significantly increased. While in the protected groups, the expression of all genes was increased in relation to the exposed groups. The expression of the aromatase gene, steroidogenic acute regulatory protein gene and caspase 3 was significantly increased in the protected groups (Table 2).

Moreover, there was a strong positive correlation between STAR gene expression, androgen gene expression, aromatase gene expression and estrogen receptor gene expression (Figure 1, 2 and 3). Roundup was linked both directly and indirectly with considerable genetic and endocrine alterations compared with the control.

Our study elucidated that Roundup induced cytotoxicity and cell death via caspase 3 gene induction. Caspase 3 gene expression was presented at its lower level in the control group $(5.5 \pm 1.7)$. It increased significantly in exposed group (1) $(5.48 \pm 1.69)$ with more increase in group (2) $(10.18 \pm 0.63)$. With administration of vitamin $\mathrm{E}$ the caspase 3 gene expression significantly decreased until reaching its lowest level in the protected group (1) $(2.27 \pm 0.46)$ table (2). Meanwhile, the lower the toxic dose of Roundup the more protection delivered through vitamin $\mathrm{E}$.

\section{Histolopathological examination of testis}

Our results are confirmed by the histological examination of the testicular tissues after exposure to different doses of Roundup alone or with vitamin $\mathrm{E}$ in comparison with the normal cell type. Control group slides showed seminiferous tubules with normal germinal epithelium with 
normal tissues (Figure 3. A). Exposed groups $500 \mathrm{mg} / \mathrm{kg}$ and $750 \mathrm{mg} / \mathrm{kg}$ (Figure 3.B\&.C) showed cell death, lack of adhesion, shrinking and fragmentation in apoptotic bodies. DNA condensation, disrupted cytoarchitecture of the gonad, hyperplasia of Leydig cells, necrosis of the germinal epithelium, detachment of the seminiferous tubules, dilatation of the interstitial vessel and congestion with evidence of stasis were observed more frequently with increasing the dose of Roundup. However, vitamin E administration significantly reduced these lesions (Figure3.D).

Table (1): Primer sequences used for RT-PCR.

\begin{tabular}{|c|c|}
\hline Primer & Sequence \\
\hline Aromatase & $\begin{array}{l}\text { Forward 5'- GCTTCTCATCGCAGAGTATCCGG-3' } \\
\text { Reverse } 5^{\prime} \text { - CAAGGGTAAATTCATTGGGCTTGG-3' }\end{array}$ \\
\hline $\begin{array}{l}\text { Steroidogenic } \\
\text { Regulatory }\end{array}$ & $\begin{array}{l}\text { Forward 5'- CACAGTCATCACCCATGAGC-3' } \\
\text { Reverse 5'- AGCTCTGATGACACCGCTTT-3' }\end{array}$ \\
\hline Estrogen Receptor & $\begin{array}{l}\text { Forward 5'- AATTCTGACAATCGACGCCAG-3' } \\
\text { Reverse 5'- GTGCTTCAACATTCTCCCTCCTC-3' }\end{array}$ \\
\hline Progesterone Receptor & $\begin{array}{l}\text { Forward 5'- CCCACAGGAGTTTGTCAAGCTC-3' } \\
\text { Reverse 5'- TAACTTCAGACATCATTTCCGG-3' }\end{array}$ \\
\hline Caspase 3 & $\begin{array}{l}\text { Forward 5'- ATGGACAACAACGAAACCTC-3' } \\
\text { Reverse 5'- TTAGTGATAAAAGTACAGTTCTT-3' }\end{array}$ \\
\hline $\begin{array}{l}\text { Glyceraldehyde 3- } \\
\text { phosphate dehydrogenase }\end{array}$ & $\begin{array}{l}\text { Forward 5'- CTCCCATTCTTCCACCTTTG-3' } \\
\text { Reverse 5'- CTTGCTCTCAGTATCCTTGC-3' }\end{array}$ \\
\hline
\end{tabular}

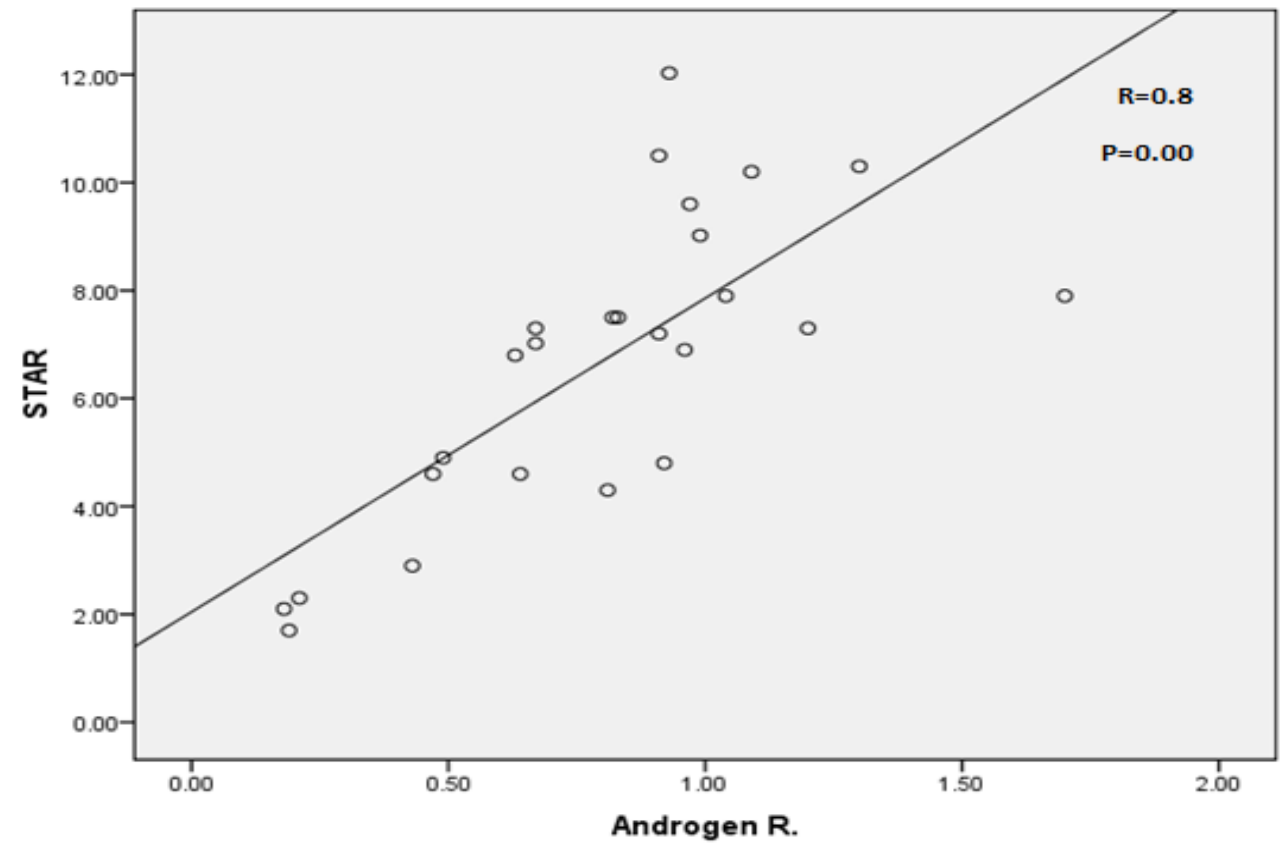

Figure (1): Correlation between androgen gene expression and STAR gene expression among different groups. 
Table (2): Mean \pm SD levels of aromatase, steroidogenic acute regulatory protein, estrogen receptor, androgen receptor and caspase genes expression among different groups.

\begin{tabular}{|c|c|c|c|c|c|c|c|}
\hline & \multirow[b]{2}{*}{ Control } & \multicolumn{2}{|c|}{ Exposed groups } & \multirow[b]{2}{*}{ P value } & \multicolumn{2}{|c|}{ Protected groups } & \multirow[b]{2}{*}{$\begin{array}{l}P \\
\text { value }\end{array}$} \\
\hline & & $\begin{array}{l}\text { Group (1) } \\
\text { Round } \\
\mathbf{5 0 0}\end{array}$ & $\begin{array}{l}\text { Group (2) } \\
\text { Round } \\
750\end{array}$ & & $\begin{array}{l}\text { Group (1) } \\
\text { Round } \\
\text { 500+vit E }\end{array}$ & $\begin{array}{l}\text { Group (2) } \\
\text { Round } \\
\text { 750+vit E }\end{array}$ & \\
\hline Aromatase & $1.18 \pm 0.34$ & $0.66 \pm 0.29$ & $0.31 \pm 0.18$ & $0.021 *$ & $0.82 \pm 0.09$ & $0.74 \pm 0.12$ & $0.009 *$ \\
\hline Estrogen R. & $1.38 \pm 0.26$ & $0.95 \pm 0.16$ & $0.53 \pm 0.10$ & $0.016 *$ & $1.35 \pm 0.31$ & $1.11 \pm 0.19$ & 0.751 \\
\hline Androgen $R$. & $1.19 \pm 0.33$ & $0.65 \pm 0.11$ & $0.30 \pm 0.14$ & $0.009 *$ & $1 \pm 0.14$ & $0.86 \pm 0.12$ & 0.465 \\
\hline STAR & $10.19 \pm 1.48$ & $5.52 \pm 1.29$ & $2.72 \pm 1.14$ & $0.009 *$ & $8.26 \pm 1.00$ & $6.74 \pm 1.11$ & $0.02 *$ \\
\hline Caspase 3 & $1.15 \pm 0.27$ & $5.48 \pm 1.69$ & $10.18 \pm 0.63$ & $0.009 *$ & $2.27 \pm 0.46$ & $3.19 \pm 1.22$ & $0.009 *$ \\
\hline
\end{tabular}
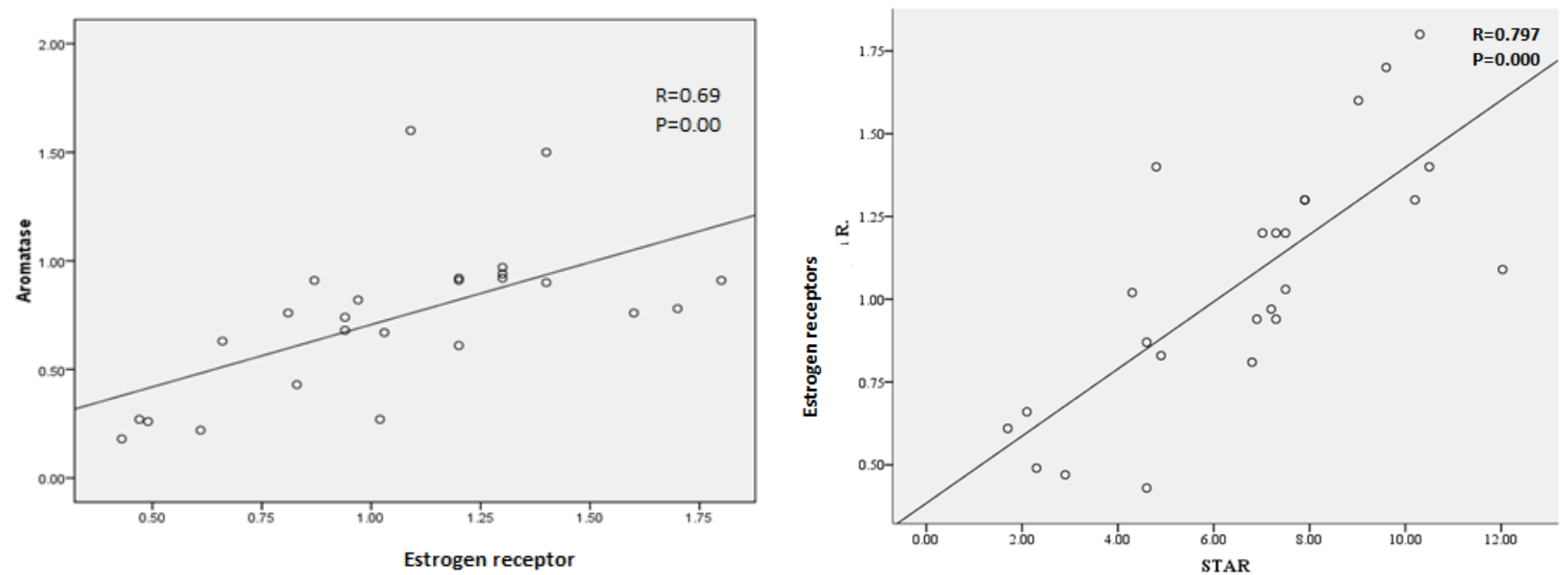

Figure (2): Correlation between aromatase and STAR genes expression and estrogen receptor gene expression among different groups.
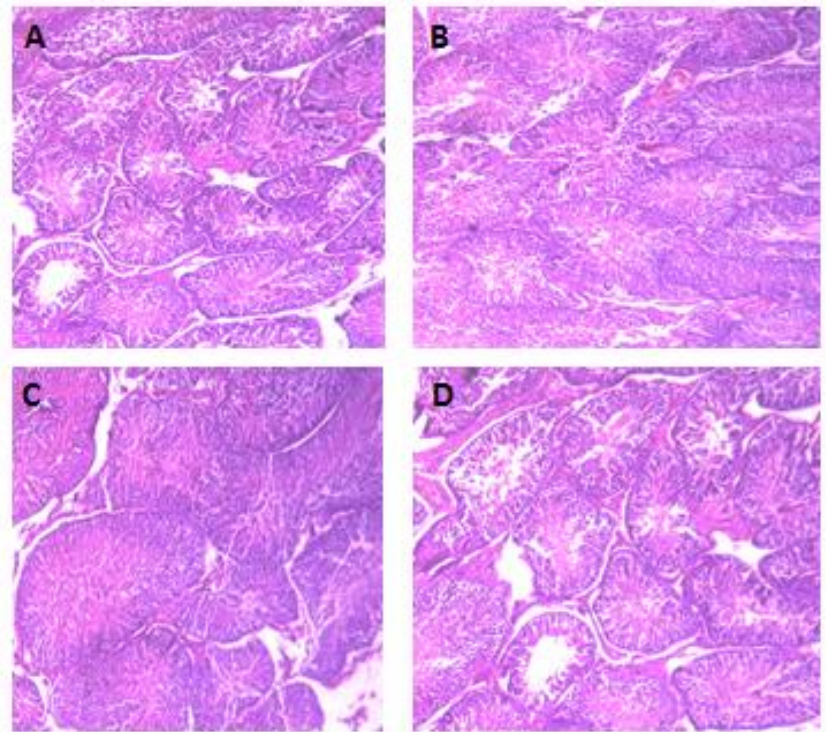

Figure (3): Histopathological testicular examination of control group (A), exposed groups $500(\mathrm{~B}), 750(\mathrm{C})$, treated group with vit $\mathrm{E}(\mathrm{D})$. 


\section{DISCUSSION}

Roundup is a broad-spectrum worldwide used herbicide, found as a contaminant in rivers. Its residues enter the food chain. Roundup contains acid glyphosate and polyethoxylated tallowamine as adjuvants. Roundup is always more toxic than its active ingredient (Richard et al., 2005).

Although Roundup is environmentally unsafe, the European Commission has ignored or dismissed many Roundup genotoxic findings disclosed in many scientific literatures. Many of these effects are found at very low doses, comparable to levels of pesticide residues found in food and the environment (Gasnier et al., 2009 ; Richard et al., 2005).

Round up cytogenotoxicity and the protective effects of vitamin $\mathrm{E}$ were tested using animal model (mice).

Our results revealed that the expression of aromatase, STAR, estrogen and androgen receptor genes were significantly decreased in exposed groups. Roundup herbicide showed direct or indirect considerable endocrine genetic alterations compared with the control. In the protected groups, estrogen and androgen receptor genes were insignificantly increased. However, the expression of the aromatase, STAR genes were significantly increased.

This goes in agreement with Walsh and his colleagues (2000) who stated that Roundup interferes with steroidogenic acute regulatory (StAR) protein.

Gasnier and his colleagues (2009) concluded that Roundup interfered with endocrine activities in human cell lines through inhibition of androgen to estrogen conversion and disruption of estrogen and androgen transcriptional activities.

Glyphosate formulations inhibit the activity of oxidase enzymes. One of these enzymes is aromatase, which is involved in the synthesis of sex hormones from cholesterol, specifically the conversion of male hormones to female hormones (Walsh et al., 2000).

Benachour and his colleagues (2007) and Richard and his colleagues (2005)indicated that Roundup causes more aromatase inhibition than the pure form of glyphosate in human embryonic cells and human placental cell cultures at concentrations lower than those found with agricultural use, and this effect increases with concentration as demonstrated in our results.

Gasnier and his colleagues (2009) stated that glyophosate-based pesticides increase aromatase mRNA levels followed by a return to normal level this is called the biphasic effect.

Our study elucidated Roundup induced cytotoxicity and cell death via caspase 3 gene induction. The lowest level of caspase 3 gene expression presented in the control group and it significantly progressively increased in the exposed groups. With administration of vitamin $E$ the caspase 3 gene expression significantly decreased till reaching its lower level in protected group.

Gasnier and his colleagues (2009) showed that Roundup was able to induce apoptosis via activation of caspase 3 while, Martini and his colleagues (2012) stated that a glyphosate-based herbicide induced apoptosis through inhibition of mammalian cell line proliferation and differentiation, this type of apoptosis can be inhibited through vitamin $\mathrm{E}$ (Martini et al., 2012). 
Marc and his colleagues (2004) stated that Roundup induced cell cycle dysfunction through inhibition of DNA synthesis. The extent of DNA synthesis inhibition correlated with the cell dysfunction and death.

Koller and his colleagues (2012) found that inhalation glyphosate exposure may cause DNA damage and cancer in humans. They found genotoxic effects after short exposure (20 minutes) to very low concentrations that correspond to a 450-fold dilution of spraying used in agriculture.

Ognjanovic and his colleagues (2003) mentioned in their study that pretreatment with vitamin $E$ exhibited a protective role on the xenobiotic toxic effects through decreased oxidative stress as well as increased enzymatic and non-enzymatic components of antioxidant defense system.

Our results are confirmed by the morphological examination of the testis after exposure to different doses of Roundup alone or with vitamin $\mathrm{E}$ in comparison with the normal cell type. Vitamin E administration significantly reduced the testicular lesions.

Ikpeme and his colleagues (2012) had the same results. However, they stated that co-administration with ascorbic acid reduced the degree of testicular lesions.

Vitamin $\mathrm{E}$ is a primary antioxidant that plays an important role in protecting cells against pesticides' toxicity by inactivating the generated free radicals.

Active oxygen species and oxidative stress play an important role in genotoxicity. Dietary antioxidants such as vitamin $E$ had potential protective effects against oxidative stress induced genotoxicity (Ognjanović et al., 2003).
Singh and his colleagues (2008) clearly demonstrated the protective effects of vitamin $E$ in attenuating atrazine-induced DNA damage. This coincides with what we found regarding the protective effects of vitamin E against Roundup cytogenotoxicity . In our study coadministration of vitamin E $(200 \mathrm{mg} / \mathrm{kg}$ body weight) along with Roundup resulted in increasing endocrinal gene expressions; furthermore it decreased cellular apoptosis through caspase 3 gene inhibition.

Ustuner and his colleagues (2010) had the same results regarding the protective role of vitamin $\mathrm{E}$ as it decreases apoptosis. Also our results coincide with Ahmed and his colleagues (2013) who stated that vitamin E supplementation decreased the apoptosis in treated groups.

Our study reported that there was a link between endocrinal cytogenotoxicity and Roundup exposure. Vitamin E can protect against these dangerous effects.

\section{CONCLUSION}

Roundup toxicity caused alteration of gene expression e.g. aromatase gene, STAR gene, estrogen receptor gene and androgen receptor gene and affects cellular integrity by increasing apoptosis. Administration of the vitamin $\mathrm{E}$ before and during exposure to Roundup can reduce and protect against its toxicity. The toxicological effects increased with increasing toxic dose and decreased with administration of Vitamin E. 


\section{REFERENCES}

Ahmed MA, Hassan AF, Ahmed OG. (2013) The Impact of Vitamin E Supplementation on Urinary Bladder Contractility in Streptozotocin-Induced Diabetic Rats. IJMBS. 5(1):4-14.

Altuntas I. and Delibas N. (2002) The effects of fenthion on lipid peroxidation and some liver enzymes: the possible protective role of vitamins E and C, Turk. J. Med. Sci. 32: 293-297.

BattaglinW, Kolpin DW, Scribner EA and Kuivila KM. (2005) Glyphosate, other herbicides and transformation products in Midwestern streams, J. Am. Water Resour. Assoc. 4: 323-332.

Benachour N, Sipahutar H, Moslemi $S$ and Gasnier $C$ et al. (2007) Time and Dose-Dependent Effects of Roundup on Human Embryonic and Placental Cells. Arch. Environ. Contam. Toxicol. 53(1):126-33.

Chan YH. (2003) Biostatistics102: Quantitative Data - Parametric \& Non-parametric Tests. Singapore Med J. 44(8): 391-396.

Costa W.F., Nepomuceno J.C. (2006) Protective effects of antioxidant vitamins and minerals on the genotoxicity of doxorubicin in somatic cells of Drosophila melanogester, Environ. Mol. Mutagen. 47: 18-24.

Faiola B., Fuller E.S., Wong V.A., Pluta L., Abernethy D.J., Rose J., Recio L (2004). Exposure of hematopoietic stem cells to benzene or 1.4-benzoquinone induces genderspecific gene expression, Stem Cells, 22: 750758.

Feron VJ, Cassee FR, Groten JP and van Vliet PW et al. (2002)
International issues on human health effects of exposure to chemical mixtures. Environ. Health Perspect.110: 893-899.

Fournier M, Cyr D, Blakley B and Boermans $\mathrm{H}$ et al. (2000) Phagocytosis as a biomarker of immunotoxicity in wildlife species exposed to environmental xenobiotics. Am. Zool. 40: 412420.

Gasnier C, Dumont C, Benachour N and Clair E et al. (2009) Glyphosate-based herbicides are toxic and endocrine disruptors in human cell lines. Toxicology. 262:184-191.

Gobi $M$ and Gunasekaran P. (2010) Effect of Butachlor Herbicide on Earthworm Eisenia fetida-Its Histological Perspicuity. Applied and Environmental Soil Science. 14.

Ikpeme EV, Udensi O, Ekaluo UB, and Solomon TO. (2012) Efficacy of Ascorbic Acid in Reducing Glyphosate-Induced Toxicity in Rats. British Biotechnology Journal. 2(3): 157-168.

Koller VJ et al. (2012) Cytotoxic and DNA-damaging properties of glyphosate and Roundup in humanderived buccal epithelial cells 163 . Arch. Toxicol. 86 (5): 805-13.

Livak KJ and Schmittgen TD. (2001) Analysis of Relative Gene Expression Data Using Real-Time Quantitative PCR and the 22DDCT. 25:402-408.

Marc J, Mulner-Lorillon $O$ and Bellé R. (2004) Glyphosate-based pesticides affect cell cycle regulation161. Biol Cell. 96 (3): 245-9.

Marc J and Bellé R. (2004) Formulated Glyphosate Activates 
the DNA-Response Checkpoint of the Cell Cycle Leading to the Prevention of G2/M Transition Toxicological Sciences. 82 (2): 436-442.

Martini CN et al. (2012) A commercial formulation of glyphosate inhibits proliferation and differentiation to adipocytes and induces apoptosis in 3T3-L1 fibroblasts. Toxicol. In Vitro. 26 (6): 1007-13.

Ognjanović B I, Pavlović S Z, Maletić, SD and IKIĆ RV et al. (2003) Protective Influence of Vitamin E on Antioxidant Defense System in the Blood of Rats Treated with Cadmium Physiol. Res. 52: 563-570.

Richard S, Moslemi S, Sipahutar H and Benachour $\mathrm{N}$ et al. (2005) Differential Effects of Glyphosate and Roundup on Human Placental Cells and Aromatase. Environ Health Perspect. 113 (6): 716-720.

Singh M, Kaur P, Sandhir $R$ and Kiran R. (2008) Protective effects of vitamin $E$ against atrazineinduced genotoxicity in rats. Mutat
Res. 654(2):145-9.

Siu SY, Lam PK, Martin $M$ and Caldwell CW et al. (2008) The use of selected genotoxicity assays in green-lipped mussel (Perna viridis): a validation study in Hong Kong coastal waters. Mar. Pollut. Bull. 57: 479-492.

Ustuner MC, Kabay S, Ozden H, Guven G, Yucel M, Olgun EG, et al. (2010) The Protective Effects of Vitamin $\mathrm{E}$ on Urinary Bladder Apoptosis and Oxidative Stress in Streptozotocin-induced Diabetic Rat. Urology. 7(4):902-6.

Walsh LP, Mccormick C, Martin C and Stocco DM. (2000) Roundup inhibits steroidogenesis bydisrupting steroidogenic acute regulatory (Star) protein expression. Environ. Health Perspect. 108(8): 769-776.

Yousef M.I., Awad T.I., Mohamed E.H. (2006) Deltamethrin-induced oxidative damage and biochemical alterations in rat and its attenuation by Vitamin E, Toxicology. 227: 240-247. 


\section{الملخص العريى}

الدور الوقائى لفيتامين( هـ) ضد الاثار السمية الجينية لمادة الراوند اب على انسجة الخصية فى ذكور الجرذان

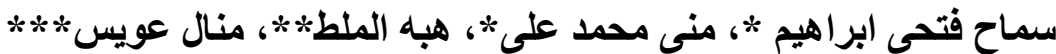

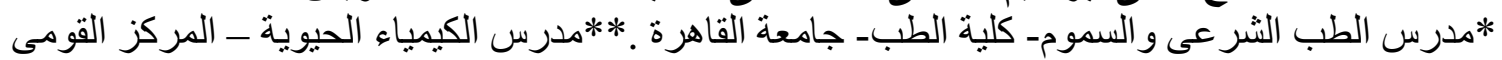

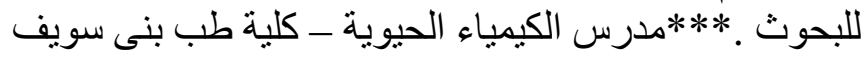

تعتبر مادة الراوند اب مبيد عثبى عالمى ذو اثار خلوية وسامة للجينات وقد تم اختبار السمية الور اثية لمادة

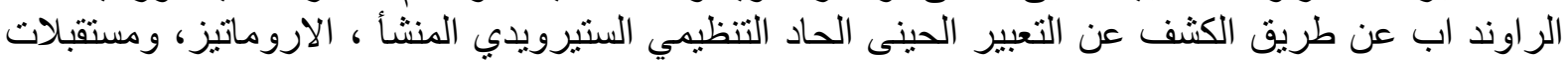

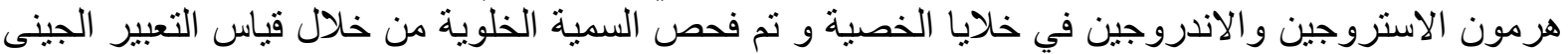
لكاسباس3 و تقييم تعبير ات الجينات من خلال جهاز

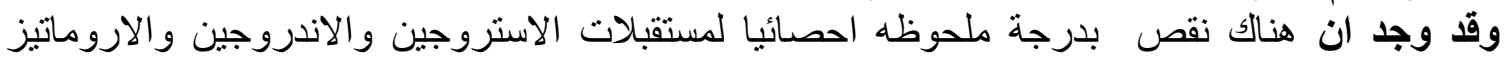

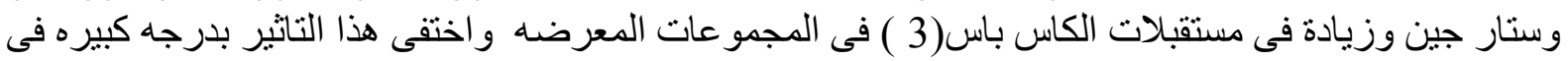

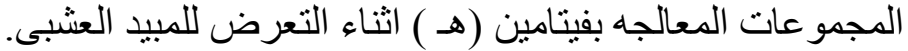

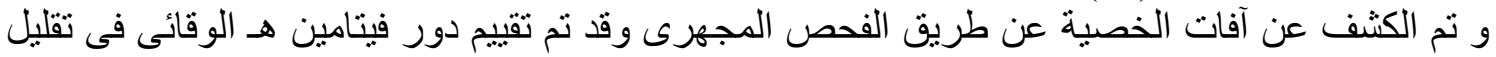

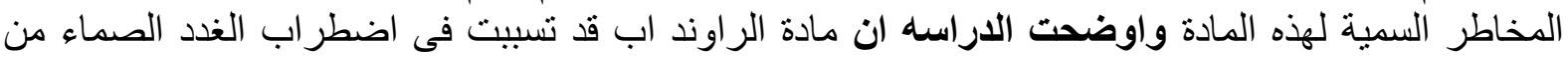

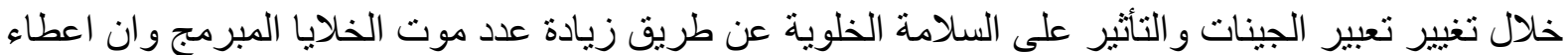
فيتامين هـ قبل و اثناء التعرض لهذه المادة يؤدى الى تقليل والحماية من الاثار الجينية السمية على الغدد الصماء لهذه المادة.

RT- PCR الكلمات الدالة: الراوند اب، السمية الور اثية،أنسجة الخصية، فيتامين( هـ) 